\title{
Consumer Guilt: A Model of Its Antecedents and Consequences
}

\author{
Tüketicilerde Suçluluk Duygusu: Öncül ve Sonuçları Üzerine Bir Model \\ Ayla ÖZHAN DEDEOĞLU1', İpek KAZANÇOĞLU²
}

\begin{abstract}
Consumer guilt is a feeling which results from one's recognition of having failed to achieve or violated internalized personal or social moral standards in the context of consumption. The present study aims to contribute to current knowledge of consumer guilt by offering a comprehensive structural model of consumer guilt, its antecedents and consequences. The findings reveal that regret due to action, regret due to inaction, transgression of norms, self-control failures and indulgence in hedonic desires are the antecedents that significantly explain consumer guilt. Among coping responses studied in literature, only the ones that relate to reparative action, psychological repair work and justification significantly loaded to coping responses factor. Comparison of respondents with high and low guilt scores revealed significant differences.
\end{abstract}

Keywords: Consumer guilt, regret, transgressions, self-control failures, indulgence, coping responses.

\section{INTRODUCTION}

Guilt, a negative self-conscious emotion, has been frequently employed by marketing practitioners, especially advertisers, to influence consumer behavior (Cotte and Ritchie 2005; Hibbert et al. 2007; Soscia et al. 2008). Consumer guilt has been researched along with its antecedents, such as impulsive and compulsive consumption (Hassay and Smith 1996; Miao 2011; O'Guinn and Faber 1989; Puri 1996; Rook 1987; Sengupta and Zhou 2007), hedonism, desire and indulgences (Belk et al. 2003; Kivetz and Simonson 2002; Ramanathan and Williams 2007; Sela, Berger and Liu 2008; Okada 2005; Xu and Schwarz 2009). Some other studies focused on types and consequences of consumer guilt (Bagozzi et al. 2000; Cooke, Meyvis and Schwartz 2001; Meyvis and Cooke 2007; Tsiros and Mittal 2000) and consumers' coping responses (Dahl et al. 2005; Duhachek 2005; Kahn, Dhar and Fischbach 2009; Yi and Baumgartner 2004).

Despite the great deal of interest, Dedeoglu and Kazancoglu (2010) argued that there still remains a

\section{ÖZET}

Tüketicilerde suçluluk duygusu bireyin, tüketim bağlamında, içselleşmiş kişisel ya da sosyal ahlaki standartları ihlal ettiğini ya da bu standartlara erişemediğini fark etmesi sonucunda oluşmaktadır. Bu çalışmanın amacı, tüketicilerdeki suçluluk duygusu, öncül değişkenleri ve sonuçları üzerine geniş kapsamlı yapısal bir model ile ilgili literature katkıda bulunmaktır. Bulgular eylem veya eylemsizlik nedeniyle pişmanlık, normların aşılması, kendini kontrol hataları ve hedonik arzulara olan düşkünlüğün tüketicilerde suçluluk duygularını anlamlı bir şekilde açıkladığını ortaya koymaktadır. Literatürde incelenen başa çıkma tepkileri arasında sadece düzeltici eylem, psikolojik olarak kendini rahatlatma ve mazeret bulma gözlemlenmiştir. Yüksek ve düşük suçluluk skorlarına sahip katılımcılar anlamlı olarak farklıık göstermektedirler.

Anahtar Kelimeler:Tüketicilerde suçluluk duygusu, pişmanlık, normların aşıması, kendini kontrol hataları, düşkünlük, başa çıkma tepkileri.

dearth of research that examines the dimensions of consumer guilt. In their study, they distinguished five dimensions of consumer guilt (hesitation, sadness, reluctance to spend, regret and self-blame), and proposed that this feeling is caused by transgressions, self-control failures and unjustified indulgence in hedonistic desires. Employing their theoretical framework, the present study aims to contribute to current knowledge by developing a structural model of the consumer guilt and its antecedents, and coping responses and behavioral intentions. To develop the theory of consumer guilt, the logical consequences of the theoretical framework developed by Dedeoglu and Kazancoglu (2010) are subjected to rigorous empirical test to determine the extent to which they truly represent or correspond to consumer guilt as experienced by members of a large center of population, İzmir/Turkey.

In this respect, the constructs of consumer guilt and its antecedents and consumers' coping responses are first reviewed in relation to the aims of the study. The remainder of the study consists of

${ }^{1}$ Assoc. Prof., Ege University, Faculty of Economics and Administrative Sciences, Department of Business Administration, ayla.dedeoglu@ege.edu.tr

${ }^{2}$ Assist. Prof., Ege University, Faculty of Economics and Administrative Sciences, Department of Business Administration, ipek.savasci@ege.edu.tr 
an interpretation of findings of the study with the context of consumer guilt, transgressions of norms, self-control failure, indulgence and hedonic consumption and coping responses.

\section{THEORETICAL FRAMEWORK}

\subsection{The Constructs of Consumer Guilt}

Consumer guilt is a feeling which results from one's recognition of failure to achieve, whether in realit or in ones' imagination, internalized personal or social moral standards or otherwise violating these standards in the context of consumption (Bonsu and Main 2006; Boujbel 2008; Watson and Spence 2007). Guilt feeling is a negative self-conscious emotion and rests on a sense of self-awareness and self-evaluation (Dahl et al. 2003). The causal and self-aware consumer appraises the agency (Roseman 1984; Watson and Spence 2007), i.e. take the "credit of blame (Lazarus 1991). Feelings of guilt can occur in social isolation as well as in social contexts; these feelings are likely to result from social appraisal, as they tend to arise in interpersonal relationships, especially when individuals take the agency for their actions that caused harm to valued partners, and feels empathetic concern (Baumeister et al. 1995; Dahl et al. 2005; Etxebarria 2000).

Tangney (2003) argues that guilt feelings can stimulate action control-mechanism; since it involves evaluation of a self-caused undesirable event, and informs individuals that they have violated intra- and interpersonal or social standards, it may motivate adaptive coping responses by, for instance, altering subsequent behavior (Dahl et al. 2003, 2005; Baumeister et al. 1995; Keinan and Kivetz 2008; Yi and Baumgartner 2004). Yet, there is also evidence that, in some cases, guilt can be maladaptive and lessen self-esteem (Etxebarria 2000; Burnett and Lunsford 1994).

Consumer guilt is categorized as anticipatory, reactive and proceeding guilt. Anticipatory guilt is experienced as one contemplates a transgression (Huhmann and Brotherton 1997), while reactive guilt,i.e. regret, occurs after one has committed a transgression. Proceeding guilt arises during the buying process (Lin and Xia 2009). Dedeoglu and Kazancoglu (2010) found that it is the feeling of regret that appears to be the most frequently experienced emotional construct. This can equally stem from decisions to act or from decisions not to act (Pieters and Zeelenberg 2007, Roese et al. 2007). Roese et al. (2007) argue that regrets of action and inaction are different in terms of their motivational implications; regrets of action tend to center on avoidance and are related to prevention failures (e.g., not being able to avoid an undesirable product or situation), whereas regrets of inaction tend to center on approach and are related to promotion failures (e.g., not being able to approach a desired product or situation). Regret for the purchase of utilitarian products occurs associated with a perception of value, while regret of purchase of hedonic products cause guilt feeling associated with a perception of transgression, selfindulgence and self-control failure (Miao 2011). Regret due to inaction can occur because of decisions which result not only in in missed opportunities, but also in unfulfilled needs (Dedeoglu and Kazancoglu 2010, Keinan and Kivetz 2008).

Elison (2005) warned that since multiple affects are associated with the state of guilt and varieties of guilt should be distinguished whenever possible. Guilt is often associated with other negative emotions: for instance, people may react to their own feeling of guilt with sadness (Soscia 2007). Thus, several researchers conceptualized consumer guilt as a multidimensional construct, mostly referred to a painful experience of regret, remorse, empathic concern, hesitation, self blame and self-punishment, (Bei et al. 2007, Bonsu and Main 2006; Dahl et al. 2003; Huhmann and Brotherton 1997; Lascu 1991; Lin and Xia (2009). Dedeoglu and Kazancoglu (2010) identified hesitation, sadness, reluctance to spend, regret and self-blame as the major constructs. Despite the widespread acknowledge that guilt is a multi-dimensional construct, several studieschose to concentrate on regret and remorse. Regret is experienced when a non-chosen alternative is known (or is imagined) to yield better outcomes than the chosen one (Bagozzi et al. 2000; Saffrey et al. 2008; Tsiros and Mittal 2000; Yi and Baumgartner 2004; Zeelenberg and Pieters 2007). Remorse is similar to regret in that it is focused on the action, nevertheless, it is more concerned with the issue of right versus wrong action (Ben-Ze'ev 2000) Compulsive consumption and indulgences are thought to lead to remorse (O'Guinn and Faber 1989; Faber 2000; Ramanathan and Williams 2007). Dedeoglu and Kazancoglu (2010) indicated that, in consumer culture, consumer guilt is only short-lived and superficial, and mostly experienced as a result of good and bad actions rather than right versus wrong actions. 


\subsection{Antecedents of Consumer Guilt}

Transgressions have a powerful effect on subsequent guilt, and compliance norms can evoke guilt feelings (O'Keefe 2002). Normative evaluations describe consumers' judgments of the appropriateness of making a decision in a particular buying situation (Rook and Fisher, 1995).Norms can be determined by the consumers themselves, or by others, and can be product or purchase-situation related. Committing a transgression and thus, violating internal normative or moral standards (such as buying high-involvement products on impulse, or without seeking advice from reference groups, or yielding to temptations and buying on impulse despite the negative normative evaluations) results in increased feelings of guilt (e.g. Dedeoglu and Kazancoglu 2010; Miao 2011, Tangney and Dearing 2002; Tracy, Robins, and Tangney 2007). Transgression can be experienced as exceeding boundaries set by external sources, such as reference groups and society. Likewise, conflicting internal and external norms may induce guilt among consumers.

Self-control refers to the capacity to alter one's own states and responses, and represents the capacity to resist temptations that are likely to be regretted later (Baumeister 2002). Conflicts between consumer goals and standards can undermine self-control and result in heightened feelings of guilt. Emotional fluctuations, desires, indulgences, impulsive and compulsive urges are found to play a role in conflictions between goals and standards (e.g. Keinan and Kivetz 2008; Rook 1987; Xu and Schwarz 2009). Guilt-inducing self-control failures driven by both internal and external sources are found to arise due to the failure of the consumer's selfmonitoring capabilities and one's capacity to alter the self (Cervone et al. 2006; Dedeoglu and Kazancoglu 2010). Nevertheless, regret caused by self-control failures can also help consumers to regain control and reach to a more balanced state, for instance after an indulgence, consumers, subsequently, can choose virtue over vice, and utilitarian necessities over hedonic luxuries (Ramanathan and Williams 2007). However, Chun et al. (2007) argued that this adaptive response is observed only among the consumers who need it least. In addition to failure in self-control, over-control and excessive farsightedness can also lead to feelings of missed opportunuties; Keinan and Kivetz (2008) found, though in the short-term consumers prefer acting responsibly, over time such controlled behavior generates increasing regret.

Hedonic consumption is suggested to provide people with experiential enjoyment, satisfying both psychological and physiological needs that necessities may not be able meet (Hirschman and Holbrook 1982, Xu and Schwarz 2009). In addition to feelings of pleasure, consumers could simultaneously perceive negative aspects and feel guilt. Following desires, indulgences, and impulsive and compulsive urges to buy something can cause feelings of guilt or at least mixed feelings and ambivalence (Maclnnis and Patrick 2006; Miao 2011; Mukhopadhyay and Johar 2007; O'Guinn and Faber 1989, Saldanha and Williams 2008). Although findings of several studies indicate that consumers are more likely to consume hedonic goods when they can justify their decisions (e.g. Okada 2005), they can also intentionally seek gratification of their desires to avoid fear of being without desire (Belk et al. 2003) and feelings of missing out on the pleasures of life in the long run (Kivetz and Keinan 2006). The intensity of feelings of guilt due to the indulgence can vary in each situation (Xu and Schwarz 2009). Studies of desires indicate that consumers perceive desire as exciting and tempting, on one hand, and dangerous, on the other (Belk et al. 2003). Dedeoglu and Kazancoglu (2010) demonstrated that desire objects that seem to offer magical means for transformation and belonging can cause guilt, especially when consumers realize that they fulfill their promise.

\subsection{Coping Responses to Feelings of Consumer Guilt}

It is assumed that consumers are regret-averse in most cases and try to avoid and regulate their regrets in order to regulate behavior (Zeelenberg and Pieters 2007, Roese et al. 2007). By proposing that guilt acts as a motivational state, Khan, Dhar and Fishbach (2009) propose that guilt-primes increase the motivation to avoid guilt, which guides the interpretation of means to achieve this goal state. Considering guilt as an emotional state, it is proposed that consumers tend to try to regulate and/or eliminate their guilt by means of coping strategies. Coping is defined as the set of consumers' cognitive and behavioral responses to emotionally arousing and stress inducing events, in an attempt to reach to desirable emotional states and reduced levels of stress (Duhachek 2005). In the literature of self-conscious negative emotions, coping responses have been studied as adaptive and maladaptive coping (e.g. Eppright et al. 2002; Rippetoe and Rogers 1987; Tanner, Hunt and Eppright 1991, Umeh 2004; Vincent and Dubinsky 2005; Witte 1992). Adaptive coping includes dealing with negative emotions cognitively and trying to overcome the threat by utilizing rational problem solving mecha- 
nisms and performing the recommended coping behaviors. It is also defined as problem-focused coping by Lazarus and Folkman (1984). In problem-focused coping, the consumer tries to manage the source of a negative emotional experience and act on the threat in order to change the nature of a stressor directly (Duhachek 2005, Godwin, Patterson and Johnson (1999), Yi and Baumgartner 2004). In a study of consumer reaction to guilt, it was found that engaging in reparative, compensatory actions or making promises or plans regarding future actions were the most frequently employed actions (Dahl et al. 2003).

Maladaptive coping, defined as emotion-focused coping by Lazarus and Folkman (1984) or feeling-focused strategies by Pieters and Zeelenberg (2007), does not include directly managing the source of emotions experienced as a result of a stressful situation; rather, to reduce the symptoms of negative emotions and to regulate one's emotional response, people consciously or unconsciously utilize defense mechanisms such as avoidance (suppressing or denying regret), psychological repair work or justification (e.g. Duhachek 2005, Luce 1998, Eppright et al., 2002).

In his multidimensional model of consumer coping, Duhacheck (2005) introduced alternative categories; active coping, expressive support-seeking, and avoidance. Active coping includes action coping, rational and positive thinking, whereas expressive support seeking comprises emotional venting, instrumental and emotional support. The avoidance category consists of two aspects, avoidance and denial.

Among all these responses, justification has attracted the highest level of attention from researchers (e.g. Connolly and Zeelenberg 2002; Dedeoglu and Kazancoglu 2010; Kivetz and Keinan 2006; Keinan and Kivetz 2008; Kivetz and Simonson 2002; Sela, Berger and Liu 2008; Xu and Schwarz 2009;). Okada (2005) revealed that hedonic goods consumption is more likely when the decision context allows the flexibility to justify the consumption. To get pleasure from experiential enjoyment without feeling guilty, consumers try to construct reasons for justification.

\section{FIELD SURVEY}

Dedeoglu and Kazancoglu (2010) argued that there still remains a dearth of research that examines the dimensions of consumer guilt by providing a more complete understanding and developed a phenomenological account of consumer guilt. They distinguished five dimensions of consumer guilt (hesitation, sadness, reluctance to spend, regret and self-blame) and proposed that it is felt due to transgressions, self-control failures and indulgence in hedonistic desires. Employing thia theoretical framework, the present study aims to contribute to the current body of knowledge of consumer guilt by developing a structural model of the consumer guilt and its antecedents and coping responses and behavioral intentions. To develop the theory of consumer guilt, the logical consequences of the theoretical framework developed by Dedeoglu and Kazancoglu (2010) are subjected to rigorous empirical test to determine the extent to which they truly represent and reflect consumer guilt as experienced by a larger population.

\subsection{Research Methodology}

Data were collected in Izmir/Turkey in 2011 by means of a questionnaire. In the first section, participants were asked to determine the frequency of their guilt feelings, based on a Likert scale ranging from "None (1)" to "Very frequently (6)". Responses to statements about the nature and sources of guilt and consumers' coping responses and future behavior were recorded via a five-point Likert-type scale $(1=$ strongly disagree, $5=$ strongly agree). Since the present study aims to contribute to theory development through the empirical testing of testing the theoretical framework developed by Dedeoglu and Kazancoglu (2010), the statements are developed based the findings of their qualitative study. The final section included demographic questions.

Due to the budget limitations, the study was conducted only in Izmir, the third biggest metropolitan city of Turkey. The sample was structured so as to match Izmir's demographic profile in terms of gender, marital status, age and income, yet some level of statistical deviation still exists. After a pilot test with 50 respondents, the questionnaire was revised so that inapplicable questions and ambiguous wording could be avoided. 1355 usable questionnaires were collected. The alternative hypotheses are as follows;

$\mathrm{H}_{1 \mathrm{a}}$ : Regrets due to action cause higher levels of consumer guilt.

$\mathrm{H}_{1 \mathrm{~b}}$ : Regrets due to inaction cause higher levels of consumer guilt.

$\mathrm{H}_{1 \mathrm{c}}$ : Transgression of norms causes higher levels of consumer guilt.

$\mathrm{H}_{1 \mathrm{~d}}$ : Self-control failures cause higher levels of consumer guilt.

$\mathrm{H}_{1 \mathrm{e}}$ : Hedonic consumption causes higher levels of consumer guilt.

$\mathrm{H}_{2 \mathrm{a}}$ : Consumer's level of guilt affects coping responses.

$\mathrm{H}_{3 \mathrm{a}}$ : Coping responses affect consumers' future attitudes and behavior. 


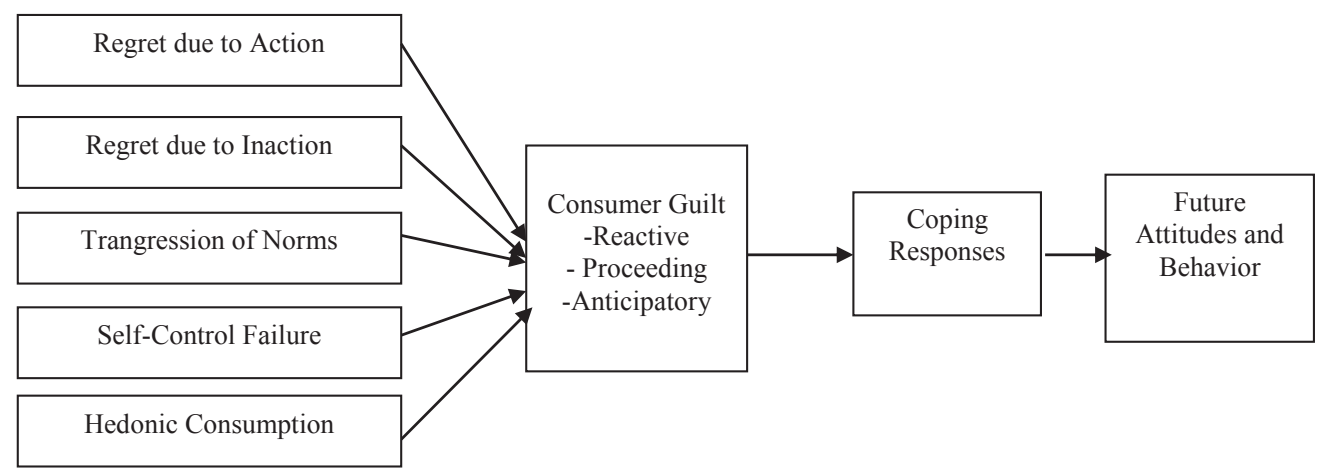

Figure 1: The Research Model

\subsection{Findings}

The majority of the respondents were male $(50.1 \%)$, single $(57 \%)$ and between $22-28$ years of age (32.1\%). Additional demographic and socio-economic characteristics of the sample appear in Table
1. $23.3 \%$ of the respondents reported frequently feeling anticipatory guilt, while $15.1 \%$ reported reactive guilt, $11.1 \%$ reported proceeding guilt. Respondents reported most often feeling guilt when buying clothing items (41.7\%), mobile phones and fashion items (39.9\%).

Table 1: Demographic Characteristics of the Sample

\begin{tabular}{|c|c|c|l|c|c|}
\hline Gender & N & $\begin{array}{c}\text { Valid } \\
\text { Percent }\end{array}$ & Marital Status & N & $\begin{array}{c}\text { Valid } \\
\text { Percent }\end{array}$ \\
\hline Male & 676 & 49.8 & Married & 772 & 57 \\
Female & 679 & 50.1 & Single & 583 & 43 \\
Total & 1355 & 100 & Total & 1355 & 100 \\
\hline Age & & & Education & 3 & \\
\hline $15-21$ & 73 & 5.38 & Illiterate & 5 & 0.22 \\
$22-28$ & 435 & 32.10 & Literate & 85 & 6.27 \\
$29-35$ & 259 & 19.11 & Primary School & 81 & 5.97 \\
$36-42$ & 163 & 12.02 & Secondary School & 400 & 29.5 \\
$43-49$ & 223 & 16.45 & High School & 719 & 53.08 \\
$50-56$ & 157 & 11.58 & University degree & 62 & 4.6 \\
$57-63$ & 35 & 2.58 & Master + & 1355 & 100 \\
$64-70$ & 11 & 0.81 & Total & & \\
Total & 1355 & 100 & & & \\
\hline Income & $\mathbf{N}$ & Valid Percent & Occupation & 264 & 11.8 \\
\hline Lower & 849 & 62.6 & Private sector employee & 247 & 18.4 \\
Medium & 386 & 28.4 & Public sector employee & 139 & 10.4 \\
Upper & 131 & 9.0 & Professional & 31 & 2.28 \\
Total & 1355 & 100 & Small-scale trader & 143 & 10.5 \\
& & & Large-scale trader & 135 & 9.96 \\
& & Student & 154 & 11.36 \\
& & & Retired & 41 & 3.03 \\
& & & Housewife & 39 & 2.87 \\
& & & Unemployed & 1355 & 100 \\
\hline
\end{tabular}

The statements that did not prove to be significant during one sample t-testing were not retained for further analyses. The structural validity of the scale was analyzed using factor analysis. Exploratory factor analyses based on principal component analysis and varimax rotation were utilized to structure the measurements of each concept. The statements that had factor loadings lower than 0.50 were removed from the study. The statements about coping responses that were retained were classified as reparative action, psychological repair work and justification.
Factor loadings of all the remaining statements ranged from 0.69 to 0.88 . Internal consistency reliability coefficients, Cronbach's alpha, were satisfactory (Table 2).

3.2.1. Comparison of Respondents with Low and High Guilt Scores

Respondents with high and low guilt scores were compared via independent-samples t-tests (Table5). Guilt scores were computed using the statements that aimed to measure the frequency of the guilt fe- 
Table 2: Extracted Factors for Guilt Statements

\begin{tabular}{|c|c|c|c|}
\hline Factors & Statements & $\begin{array}{l}\text { Factor } \\
\text { Loading }\end{array}$ & $\begin{array}{c}\text { Cumulative } \% \\
\text { of variance } \\
\text { explained }\end{array}$ \\
\hline \multirow{4}{*}{$\begin{array}{l}\text { Regret due to Action } \\
\text { (KMO=0.616;Bartlett= } \\
574,99 \\
\text { df: } 6 ; p<0.000 \\
\text { Cronbach's } \\
\text { alpha }=0.766 \text { ) }\end{array}$} & I feel guilty due to post-purchase dissonance. & 0.838 & \multirow{2}{*}{38.109} \\
\hline & I feel guilty when I buy a product that is rapidly absorbed. & 0.832 & \\
\hline & I regret buying a product that does not accord with my style. & 0.889 & \multirow{2}{*}{69.491} \\
\hline & I feel guilty when I purchase product that does not prove to be of use to me. & 0.666 & \\
\hline \multirow{4}{*}{$\begin{array}{l}\text { Regret due to Inaction } \\
(\mathrm{KMO}=0.638 ; \text { Bartlett }= \\
322.42 \\
\mathrm{df}: 6 ; \mathrm{p}<0.000, \\
\text { Cronbach's } \\
\text { alpha }=0.731)\end{array}$} & I regret not buying the products when I really needed/wanted them. & 0.844 & \multirow[b]{2}{*}{35.521} \\
\hline & $\begin{array}{l}\text { I regret not being able to buy the products when I really needed/wanted } \\
\text { them. }\end{array}$ & 0.828 & \\
\hline & $\begin{array}{l}\text { On several occasions, I had feelings of regret over missing a certain buying } \\
\text { opportunity. }\end{array}$ & 0.800 & \multirow[t]{2}{*}{64.277} \\
\hline & I have feelings of regret when I miss opportunities to buy at lower prices. & 0.707 & \\
\hline \multirow{4}{*}{$\begin{array}{l}\text { Transgression of } \\
\text { Norms } \\
\text { (KMO }=0.618 ; \text { Bartlett } \\
=339.49 \\
\text { df:6; } p<0.000 \\
\text { Cronbach's } \\
\text { alpha }=0.621)\end{array}$} & I feel equally guilt over not responding to a gift. & 0.817 & \multirow{2}{*}{33.468} \\
\hline & I feel guilty when I buy products that do not accord with my religious beliefs. & 0.809 & \\
\hline & I feel guilty when I buy products that harm the natural environment. & 0.828 & \\
\hline & $\begin{array}{l}\text { Observing people who are financially less fortunate makes me feel guilty as a } \\
\text { consumer. }\end{array}$ & 0.805 & 66.895 \\
\hline \multirow{8}{*}{$\begin{array}{l}\text { Self Control Failure } \\
(\mathrm{KMO}=0.751 ; \\
\text { bartlett }=1322.31 \\
\text { df: } 28 ; \mathrm{p}<0.000 \\
\text { Cronbach's } \\
\text { alpha }=0.671)\end{array}$} & Fear of making false purchase decisions influences my buying behavior. & 0.741 & \multirow{2}{*}{21.872} \\
\hline & Buying products without prior deliberation gives me feelings of guilt. & 0.740 & \\
\hline & Overeating gives me feelings of guilt. & 0.629 & \multirow{3}{*}{40.831} \\
\hline & $\begin{array}{l}\text { I feel guilty when I do not respond to sales person who offers me a sales } \\
\text { promotion. }\end{array}$ & 0.767 & \\
\hline & Spending money irrationally gives me feelings of guilt. & 0.737 & \\
\hline & $\begin{array}{l}\text { Buying products on installments eases the burden of payment and feelings of } \\
\text { guilt. }\end{array}$ & 0.659 & \multirow{3}{*}{58.828} \\
\hline & Guilt appeals in advertisements always make me feel guilty. & 0.812 & \\
\hline & $\begin{array}{l}\text { I have feelings of regret after a purchase when sales person compels me to } \\
\text { buy. }\end{array}$ & 0.772 & \\
\hline \multirow[b]{2}{*}{$\begin{array}{l}\text { Hedonic } \\
\text { Consumption } \\
\text { (KMO=0.600; Bartlett } \\
=249.26 \\
\text { df: } 1 ; p<0.000 \\
\text { Cronbach's } \\
\text { alpha }=0.681)\end{array}$} & I frequently have guilty feelings when I buy only for my own gratification. & 0.840 & \\
\hline & $\begin{array}{l}\text { I feel happiness and guilt simultaneously when I buy only for my own } \\
\text { gratification. }\end{array}$ & 0.840 & 70.513 \\
\hline \multirow{4}{*}{$\begin{array}{l}\text { Reactive Guilt } \\
\text { (KMO=0.640; } \\
\text { Bartlett }=203.85 \\
\text { df:6; } p<0.000 \\
\text { Cronbach's } \\
\text { alpha }=0.631 \text { ) }\end{array}$} & $\begin{array}{l}\text { Regret over buying a product causes me develop negative attitudes toward } \\
\text { the company and brand. }\end{array}$ & 0.861 & \multirow[t]{2}{*}{31.692} \\
\hline & $\begin{array}{l}\text { Previous experience of regret negatively affects my future intentions of } \\
\text { buying that product. }\end{array}$ & 0.709 & \\
\hline & Previous experience of regret affects my future buying behavior negatively. & 0.761 & \multirow{2}{*}{61.245} \\
\hline & My feelings of guilt are generally short-lived. & 0.676 & \\
\hline \multirow{2}{*}{$\begin{array}{l}\text { Anticipatory Guilt } \\
(\mathrm{KMO}=0.600 ; \\
\text { Bartlett }=119.02 \\
\mathrm{df}: 1 ; \mathrm{p}<0.000 \\
\text { Cronbach's alpha }=0.60)\end{array}$} & $\begin{array}{l}\text { Anticipating a future regret makes me behave more responsibly during } \\
\text { shopping. }\end{array}$ & 0.803 & \multirow[t]{2}{*}{64.512} \\
\hline & I do not buy expensive products in order to avoid guilt feelings. & 0.803 & \\
\hline \multirow{2}{*}{$\begin{array}{l}\text { Reparative Action } \\
(\mathrm{KMO}=0.600 ; \text { Bartlett } \\
=197,38 \\
\mathrm{df}: 1 ; \mathrm{p}<0.000 \\
\text { Cronbach's alpha }=0.63)\end{array}$} & $\begin{array}{l}\text { I try to develop alternative uses for the products which I have regretted } \\
\text { buying. }\end{array}$ & 0.827 & \multirow[b]{2}{*}{68.424} \\
\hline & When I have made a purchase which I subsequently regret, I ask for a refund. & 0.827 & \\
\hline \multirow{2}{*}{$\begin{array}{l}\text { Justification } \\
\text { (KMO=0.600; Bartlett } \\
=197.38 \\
\text { df: } 1 ; p<0.000)\end{array}$} & $\begin{array}{l}\text { In order to comfort myself and avoid guilt, I try to justify my purchase } \\
\text { behavior to myself. }\end{array}$ & 0.891 & \multirow{2}{*}{79.327} \\
\hline & $\begin{array}{l}\text { Considering the brevity of life helps me to overcome my feelings of consumer } \\
\text { guilt. }\end{array}$ & 0.891 & \\
\hline \multirow{2}{*}{$\begin{array}{l}\text { Psychological Repair } \\
\text { Work } \\
\text { (KMO=0.600; Bartlett } \\
=570.27 \\
\text { df: } 1 ; p<0.000 \\
\text { Cronbach's alpha }=0.64)\end{array}$} & I try to forget purchase experiences that cause me feelings of guilt. & 0.801 & \multirow[b]{2}{*}{64.170} \\
\hline & $\begin{array}{l}\text { Sharing guilt-inducing experiences with friends/family helps me overcome } \\
\text { guilt feelings. }\end{array}$ & 0.801 & \\
\hline \multirow{2}{*}{$\begin{array}{l}\text { Future Behavior } \\
\text { (KMO=0.600; Bartlett } \\
\text { Test }=113.241 \\
\text { df: } 1 ; p<0.000 \\
\text { Cronbach's alpha }=0.61 \text { ) }\end{array}$} & $\begin{array}{l}\text { Guilt over product purchase can cause me to cancel or postpone future } \\
\text { purchases. }\end{array}$ & 0.820 & \multirow[b]{2}{*}{67.192} \\
\hline & $\begin{array}{l}\text { Guilt over product purchase causes me to increase my self-control regarding } \\
\text { future purchase. }\end{array}$ & 0.820 & \\
\hline
\end{tabular}


elings. Respondents were grouped according to their scores in relation to their average, as high or low score.

The result of independent samples t-tests (Table 3) revealed that there are significant differences between respondents who had higher and those with lower guilt scores in regard to every source of consumer guilt, i.e. regret feelings due to action and inaction, transgression of norms, self-control failure, and hedonic consumption. Respondents with higher guilt scores were influenced by each source more than others. Although all the respondents reported low levels of anticipatory guilt, respondents with higher overall guilt scores felt greater levels of reactive, proceeding and anticipatory guilt. Moreover, being influenced more by each source, and with greater feelings of guilt, the respondents with higher guilt scores also had a greater tendency employ coping responses, such as reparative action, justification and psychological repair work.

Table 3: Independent-Samples T-Tests

\begin{tabular}{|c|c|c|c|c|c|c|c|c|}
\hline 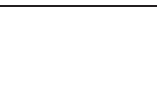 & 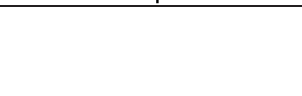 & \multirow[t]{2}{*}{$\mathbf{N}$} & \multirow[t]{2}{*}{ Mean } & \multirow{2}{*}{$\begin{array}{l}\text { Std. } \\
\text { Dev. }\end{array}$} & \multirow[t]{2}{*}{ d.f. } & \multirow[t]{2}{*}{$\mathbf{t}$} & \multicolumn{2}{|c|}{$\begin{array}{l}\text { Levene's Test } \\
\text { For Equality of } \\
\text { Variance }\end{array}$} \\
\hline & & & & & & & $F$ & Sig. \\
\hline \multirow{5}{*}{$\begin{array}{l}\text { The Sources } \\
\text { of Guilt } \\
\text { Feelings }\end{array}$} & $\begin{array}{l}\text { Regret due to Action } \\
\text { Group with higher guilt score } \\
\text { Group with lower guilt score }\end{array}$ & $\begin{array}{l}757 \\
598\end{array}$ & $\begin{array}{l}3.81 \\
2.99\end{array}$ & $\begin{array}{l}.579 \\
.771\end{array}$ & 1078 & $21.65^{*}$ & 22.0 & .000 \\
\hline & $\begin{array}{l}\text { Regret due to Inaction } \\
\text { Group with higher guilt score } \\
\text { Group with lower guilt score }\end{array}$ & $\begin{array}{l}757 \\
598\end{array}$ & $\begin{array}{l}3.26 \\
2.70\end{array}$ & $\begin{array}{l}.531 \\
.624 \\
\end{array}$ & 1173 & $17.68^{*}$ & 13.7 & .000 \\
\hline & $\begin{array}{l}\text { Transgression of Norms } \\
\text { Group with higher guilt score } \\
\text { Group with lower guilt score }\end{array}$ & $\begin{array}{l}757 \\
598 \\
\end{array}$ & $\begin{array}{l}3.44 \\
2.83\end{array}$ & $\begin{array}{l}.538 \\
.615\end{array}$ & 1192 & $19.07^{*}$ & 3.9 & .048 \\
\hline & $\begin{array}{l}\text { Self-Control Failure } \\
\text { Group with higher guilt score } \\
\text { Group with lower guilt score }\end{array}$ & $\begin{array}{l}757 \\
598 \\
\end{array}$ & $\begin{array}{l}3.64 \\
2.85\end{array}$ & $\begin{array}{l}.476 \\
.565 \\
\end{array}$ & 1165 & $27.32^{*}$ & 12.9 & .000 \\
\hline & $\begin{array}{l}\text { Hedonic Consumption } \\
\text { Group with higher guilt score } \\
\text { Group with lower guilt score }\end{array}$ & $\begin{array}{l}757 \\
598\end{array}$ & $\begin{array}{l}3.41 \\
2.48\end{array}$ & $\begin{array}{l}.894 \\
.931\end{array}$ & 1353 & $18.77^{*}$ & 2.9 & 0.09 \\
\hline \multirow{3}{*}{ Types of Guilt } & $\begin{array}{l}\text { Reactive Guilt } \\
\text { Group with higher guilt score } \\
\text { Group with lower guilt score }\end{array}$ & $\begin{array}{l}757 \\
598 \\
\end{array}$ & $\begin{array}{l}3.75 \\
3.13 \\
\end{array}$ & $\begin{array}{l}.604 \\
.808 \\
\end{array}$ & 1076 & $15.58^{*}$ & 19.5 & .000 \\
\hline & $\begin{array}{l}\text { Proceeding Guilt } \\
\text { Group with higher guilt score } \\
\text { Group with lower guilt score }\end{array}$ & $\begin{array}{l}757 \\
598\end{array}$ & $\begin{array}{l}3.70 \\
2.96\end{array}$ & $\begin{array}{l}1.06 \\
1.20 \\
\end{array}$ & 1199 & $11.90^{*}$ & 39.5 & .000 \\
\hline & $\begin{array}{l}\text { Anticipatory Guilt } \\
\text { Group with higher guilt score } \\
\text { Group with lower guilt score }\end{array}$ & $\begin{array}{l}757 \\
598 \\
\end{array}$ & $\begin{array}{l}2.69 \\
2.09\end{array}$ & $\begin{array}{l}.900 \\
.745 \\
\end{array}$ & 1350 & $13.47^{*}$ & 47.7 & .000 \\
\hline \multirow{3}{*}{$\begin{array}{l}\text { Coping } \\
\text { Responses }\end{array}$} & $\begin{array}{l}\text { Reparative Action } \\
\text { Group with higher guilt score } \\
\text { Group with lower guilt score }\end{array}$ & $\begin{array}{l}757 \\
598 \\
\end{array}$ & $\begin{array}{l}3.34 \\
2.72\end{array}$ & $\begin{array}{l}.891 \\
.939 \\
\end{array}$ & 1353 & $12.41^{*}$ & 1.5 & .215 \\
\hline & $\begin{array}{l}\text { Justification } \\
\text { Group with higher guilt score } \\
\text { Group with lower guilt score }\end{array}$ & $\begin{array}{l}757 \\
598\end{array}$ & $\begin{array}{l}3.25 \\
2.67\end{array}$ & $\begin{array}{l}.968 \\
.974\end{array}$ & 1353 & $11.04^{*}$ & .18 & .670 \\
\hline & $\begin{array}{l}\text { Psychological Repair work } \\
\text { Group with higher guilt score } \\
\text { Group with lower guilt score }\end{array}$ & $\begin{array}{l}757 \\
598 \\
\end{array}$ & $\begin{array}{l}3.41 \\
2.81\end{array}$ & $\begin{array}{l}.852 \\
.916 \\
\end{array}$ & $\begin{array}{c}1235.8 \\
07\end{array}$ & $12.42^{*}$ & 6.0 & .015 \\
\hline $\begin{array}{l}\text { Future } \\
\text { Behavior }\end{array}$ & $\begin{array}{l}\text { Future Behavior } \\
\text { Group with higher guilt score } \\
\text { Group with lower guilt score }\end{array}$ & $\begin{array}{l}757 \\
598\end{array}$ & $\begin{array}{l}3.29 \\
2.67\end{array}$ & $\begin{array}{l}.878 \\
.922\end{array}$ & 1353 & $12.51^{*}$ & 2.8 & .094 \\
\hline
\end{tabular}

\subsubsection{Model Estimation}

Results of the linear structural relation analyses indicated that both the measurement and structural equation models (SEM) have good overall model fit. Several indices described overall fit of a structural equation to the observed data, such as chi-square (X2), goodness-of-fit index (GFI), adjusted goodnessof-fit index (AGFI), root mean square residual (RMR), $X 2$ ratio, and incremental fit index (IFI). All the reliabilities computed on the basis of coefficient alpha were 0.7 or higher. Thus, all structures were measu- red satisfactorily, enabling meaningful tests of the hypotheses of interest.

The results of SEM of an aggregate model of consumer guilt, its antecedents and consequences revealed that the associations are statistically significant (Table 4). The results of the test of hypotheses of the aggregate model are as follows; $\mathrm{H} 1 \mathrm{a}(\mathrm{t}=5.70$, $\mathrm{p}<0.05), \mathrm{H} 1 \mathrm{~b}(\mathrm{t}=9.45, \mathrm{p}<0.05), \mathrm{H} 1 \mathrm{c} \quad(\mathrm{t}=4.17, \mathrm{p}<$ $0.05), \mathrm{H} 1 \mathrm{~d}(\mathrm{t}=7.05, \mathrm{p}<0.05), \mathrm{H} 1 \mathrm{e}(\mathrm{t}=8.02, \mathrm{p}<0.05)$, $\mathrm{H} 2(\mathrm{t}=11.59, \mathrm{p}<0.05), \mathrm{H} 3(\mathrm{t}=8.55, \mathrm{p}<0.05)$. Moreover, standardized regression coefficients revealed 
Table 4: The Aggregate Model of Consumer Guilt, its Antecedents and Consequences ( $N=1355)$

\begin{tabular}{|l|c|c|}
\hline \multicolumn{1}{|c|}{ Predictive Parameter Estimates } & Standardized Regression Coefficients & $\mathbf{R}^{\mathbf{2}}$ \\
\hline Action $\rightarrow$ Guilt & $0.18^{*}$ & 0.52 \\
\hline Inaction $\rightarrow$ Guilt & $0.32^{*}$ & 0.52 \\
\hline Norm $\rightarrow$ Guilt & $0.14^{*}$ & 0.52 \\
\hline Control $\rightarrow$ Guilt & $0.22^{*}$ & 0.52 \\
\hline Hedonic $\rightarrow$ Guilt & $0.26^{*}$ & 0.52 \\
\hline Guilt $\rightarrow$ Cope & $0.64^{*}$ & 0.41 \\
\hline Cope $\rightarrow$ Future & $0.62^{*}$ & 0.38 \\
\hline Overall Model Fit:GFI $=0.98$, AGFI $=0.97, C F I=0.96$, RMSEA $=0.038, \chi_{53}^{2}=157.23, p<0.01, x^{2}$ ratio $=2.69$ \\
\hline
\end{tabular}

that regret due to inaction, hedonic consumption and self-control failure had the greatest influence on consumers' guilt feelings. Regret due to inaction can occur not only due to decisions that lead to missed opportunities, but also in unfulfilled needs. Regret due to action was conceptualized in such a way as to include regrets of purchase of utilitarian products associated with a perception of low consumer value (purchase of products that are high or very low priced, infrequently used, surplus, of low utility, quickly consumed, rapidly outdated/outmoded or unable to meet expectations) but not includes regrets due to the hedonic consumption, self-control failure and transgression of norms. An interesting finding was that regret due to inaction was the single most influential source of consumer guilt, whereas regret due to action was not even among the most influential sources. The reason why guilt feelings were influenced by regrets of inaction more than regret due to action may lie in the self-report nature of the research instrument. Respondents may have utilized defense mechanisms; i.e. it may be psychologically easier for people to report their regret feelings for an action not performed than an action performed or than, for example, hedonic consumption in general. Alternatively, it can be suggested that respondents, indeed, had greater feelings of guilt for indulging themselves in hedonic consumption, losing selfcontrol and transgressing norms than, for the purchase of utilitarian products associated with a perception of lower consumer value.

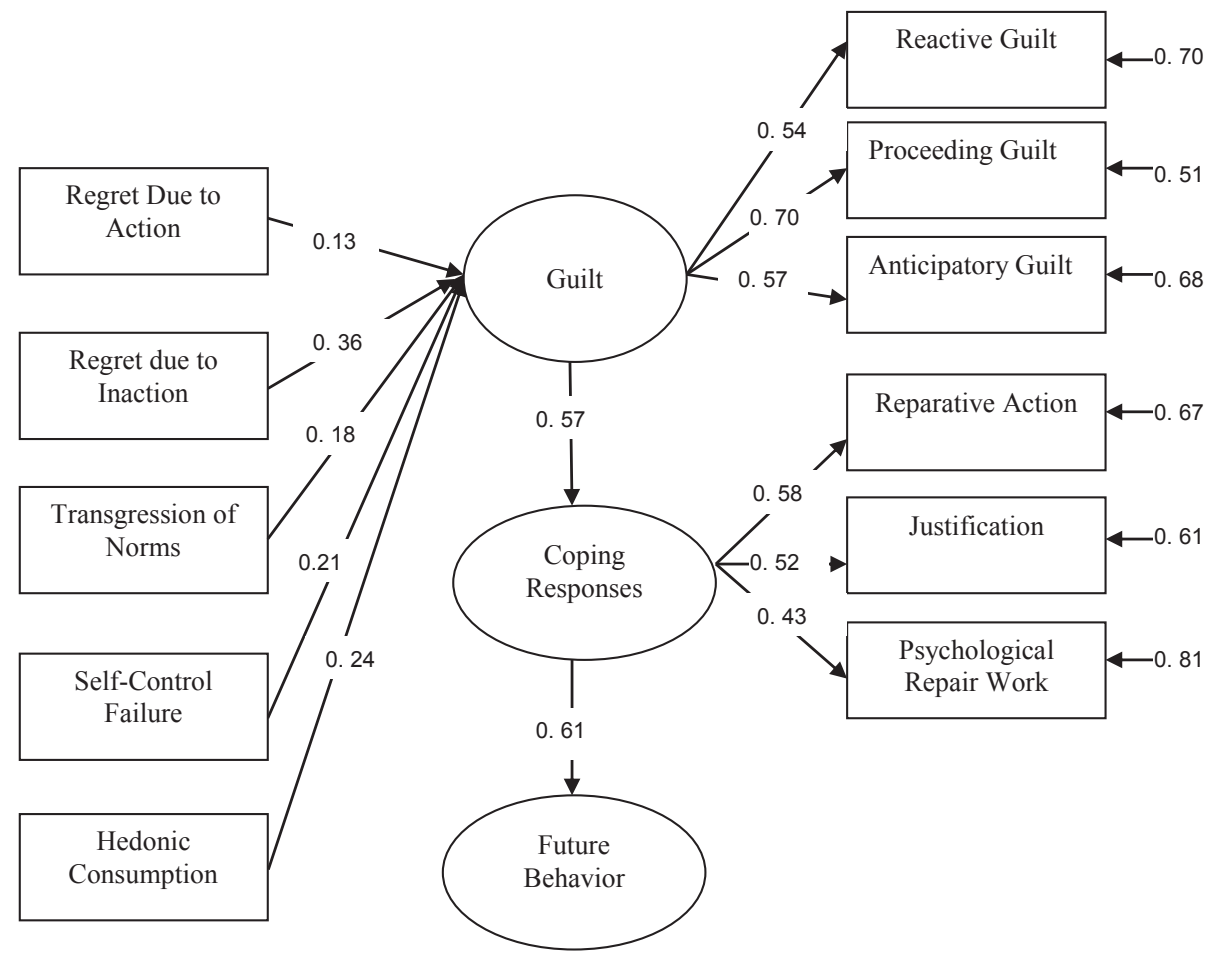

Chi-square $=115.49, \mathrm{df}=53, \mathrm{p}$-value $=0.000, \mathrm{RMSEA}=0.039$

Figure 2: The Model of Consumer Guilt, its Antecedents and Consequences for the Group with High Consumer Guilt Score $(\mathrm{N}=757)$ 


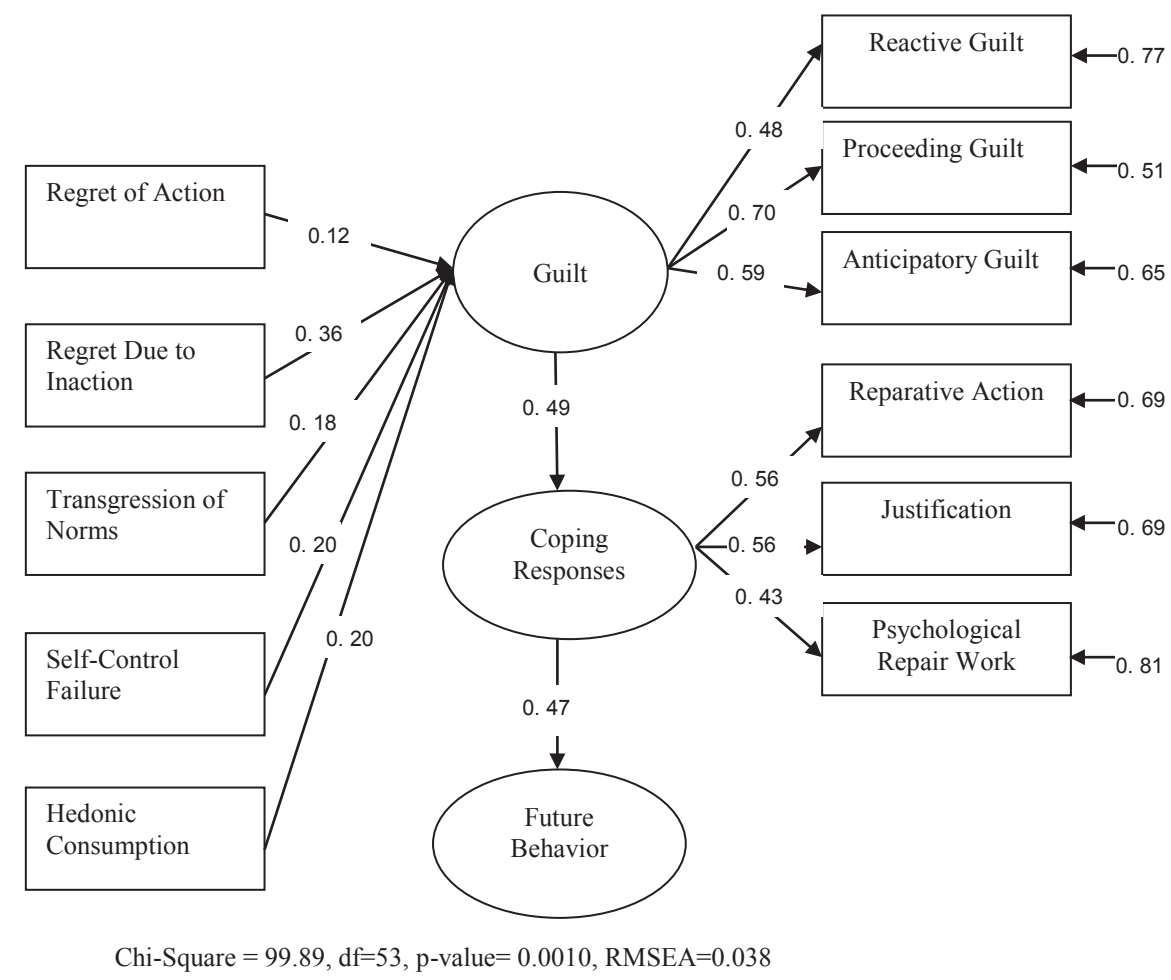

Figure 3: The Model of Consumer Guilt, its Antecedents and Consequences for the Group with Low Consumer Guilt Score $(\mathrm{N}=598)$

The findings also revealed that proceeding guilt was better able to account for consumer guilt feelings than other types of guilt ( $R 2=0.49)$, and reactive guilt was better able to account for consumer guilt feelings than other types of guilt $(\mathrm{R} 2=0.30)$. Thus, it can be proposed that respondents were mostly influenced by proceeding guilt. Moreover, considering the short-lived and superficial nature of guilt feelings (Dedeoglu and Kazancoglu 2010), respondents who coped with their guilt feelings via justification, reparative action and psychological repair work may have been able to overcome their negative feelings and therefore have no clear memory of the event.

In order to find the extent to which the associations between the sources of consumer guilt, guilt feelings, coping responses and future behavior differ between the higher and lower guilt score groups, the same SEM procedure was repeated and two different models were obtained(Figure 2 and 3). Both models had satisfactory fit to the observed data (Table 5).

The results of SEM of the two different submodels of consumer guilt, its antecedents and consequences revealed that all the associations are statistically significant (Table 5). The results of the test of hypotheses of the model of the higher guilt score group are as follows; $\mathrm{H} 1 \mathrm{ah}(\mathrm{t}=3.33, \mathrm{p}<0.05), \mathrm{H} 1 \mathrm{bh}$ $(t=7.78, p<0.05), H 1 c h(t=3.98, p<0.05), H 1 d h$ $(t=5.15, p<0.05)$, H1eh $(t=5.73, p<0.05), H 2 h(t$ $=8.04, p<0.05), H 3 h(t=7.66, p<0.05)$. The results of the test of hypotheses of the model of the lower guilt score group are as follows; $\mathrm{H} 1 \mathrm{al}(\mathrm{t}=2.64, \mathrm{p}<$ 0.05), $\mathrm{H} 1 \mathrm{bl}(\mathrm{t}=6.34, \mathrm{p}<0.05), \mathrm{H} 1 \mathrm{cl}(\mathrm{t}=3.42, \mathrm{p}<0.05)$, $\mathrm{H} 1 \mathrm{dl}(\mathrm{t}=4.15, \mathrm{p}<0.05), \mathrm{H} 1 \mathrm{e}(\mathrm{t}=4.08, \mathrm{p}<0.05), \mathrm{H} 2 \mathrm{l}$ $(t=5.80, p<0.05), H 3 l(t=4.48, p<0.05)$. The data provided satisfactory support for the proposed associations as well.

A comparison of the models of the higher and lower guilt score groups revealed that regret due to inaction was again the most important influence on consumer guilt for both groups. However, the group with higher guilt score was influenced to a greater extent by hedonic consumption, self-control failure and regret due to action. It can be proposed that in addition to regret due to inaction, the two main sources that influence consumers' guilt feelings are hedonic consumption and self control failure. All the sources significantly increased consumer guilt feelings of both groups. 
Table 5: Group Comparisons

\begin{tabular}{|c|c|c|c|c|}
\hline \multirow{2}{*}{$\begin{array}{l}\text { Predictive Parameter } \\
\text { Estimates }\end{array}$} & \multicolumn{2}{|c|}{$\begin{array}{l}\text { Group with Higher Guilt Score } \\
\text { Model ( } N=757)\end{array}$} & \multicolumn{2}{|l|}{$\begin{array}{l}\text { Group with Lower Guilt Score } \\
\text { Model }(N=598)\end{array}$} \\
\hline & $\begin{array}{l}\text { Standardized Regression } \\
\text { Coefficients }\end{array}$ & $\mathrm{R}^{2}$ & Standardized Regression Coefficients & $\mathrm{R}^{2}$ \\
\hline Action $\rightarrow$ Guilt & $0.13^{*}$ & 0.53 & $0.12^{*}$ & 0.48 \\
\hline Inaction $\rightarrow$ Guilt & $0.36^{*}$ & 0.53 & $0.36^{*}$ & 0.48 \\
\hline Norm $\rightarrow$ Guilt & $0.18^{*}$ & 0.53 & $0.18^{*}$ & 0.48 \\
\hline Control $\rightarrow$ Guilt & $0.21^{*}$ & 0.53 & $0.20^{*}$ & 0.48 \\
\hline Hedonic $\rightarrow$ Guilt & $0.24^{*}$ & 0.53 & $0.20^{*}$ & 0.48 \\
\hline Guilt $\rightarrow$ Cope & $0.57^{*}$ & 0.37 & $0.49^{*}$ & 0.22 \\
\hline Cope $\rightarrow$ Future & $0.61^{*}$ & 0.33 & $0.47^{*}$ & 0.24 \\
\hline Overall Model Fit & \multicolumn{2}{|c|}{ 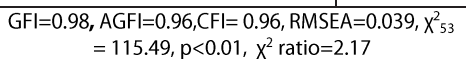 } & \multicolumn{2}{|c|}{$\begin{array}{c}\mathrm{GFI}=0.97, \mathrm{AGFI}=0.96, \mathrm{CFI}=0.95, \mathrm{RMSEA}=0.038, \mathrm{x}^{2}{ }_{53}= \\
99.89, \mathrm{p}<0.01, \mathrm{x}^{2} \text { ratio }=1.88\end{array}$} \\
\hline
\end{tabular}

The respondents with high guilt scores revealed a much greater use of coping responses. An improved comprehension of their guilt-inducing behavior may be responsible for these respondents' higher levels of reparative actions, psychological repair work and justification. Justification $(R 2=0.39)$ was found as the most employed coping response of the Group with higher guilt score, while reparative action $(R 2=0.31)$ and justification ( $R 2=0.31$ ) were the most employed coping responses of the lower guilt score group.

Moreover, although the use of coping responses significantly explained the future behavior of both groups, it can be claimed that the explanatory power of coping responses is stronger for the higher guilt score group (Table 5). Improved comprehension and evaluation of their past guilt-inducing behavior might have encouraged these respondents to try to cope with their guilt feelings in addition to alter their future behavior. They were comparably more disposed to cancel or postpone their next future purchases and impose more self-control in relation to consumption subsequent to a purchase that led to feelings of guilt (Table 3).

\section{CONCLUSION}

The present study represents an attempt to contribute to current knowledge of consumer guilt by developing a structural model of the consumer guilt, its antecedents and consumers' coping responses. To develop the theory of consumer guilt, the logical consequences of the theoretical framework developed by Dedeoglu and Kazancoglu (2010) are subjected to rigorous empirical testing to determine the extent to which they truly represent and reflect consumer guilt as experienced by members of a large center of population, Izmir/Turkey.

The findings provide support for the theoretical framework of Dedeoglu and Kazancoglu (2010). It was shown that regret due to action, regret due to inaction, transgression of norms, self-control failures and indulgence in hedonic desires are, to a consi- derable extent, able to account for consumer guilt. Among these antecedents, regret due to inaction, self-control failures and hedonic consumption were observed as those that most influenced these Turkish consumers' guilt feelings. Regret due to inaction can occur because of decisions that lead not only to missed opportunities, but also in unfulfilled needs. The reason for the greater influence of regrets of inaction more compared to regret due to action may lie in the self-report nature of the research instrument. Respondents may have utilized defense mechanisms; it may be psychologically easier for people to report their regret feelings for inaction than action or than, for example, hedonic consumption. Alternatively, it can be suggested that respondents did indeed feel more guilt over indulging themselves in hedonic consumption, losing self-control and promotion failures (Roese et al. 2007) than over the purchase of utilitarian products associated with a perception of lower consumer value.

Although all guilt types significantly explained consumer guilt, proceeding guilt was the type that had the most influence. Considering the short-lived and superficial nature of guilt feelings (Dedeoglu and Kazancoglu 2010), respondents who were able to cope with their guilt feelings may have overcome their negative feelings and have no clear memory of the event.

Among coping responses studied in literature, only those relations to reparative action, psychological repair work and justification were significantly loaded to coping responses factor. Respondents were able to cope with their guilt feelings by developing alternative uses of the product purchases which they regretted, returning the product, trying to justify their purchase behavior to themselves, sharing their guilt-inducing experience with their immediate environment, and trying to forget it. It was also revealed that coping responses also influence consumers' future behavior. 
The associations between the sources of consumer guilt, guilt feelings, coping responses and future behavior differed between the higher and lower score groups. Although regret due to inaction was the most important influence of consumer guilt for both groups, the higher guilt score group was significantly more influenced by hedonic consumption, self-control failure and regret due to action. It can be proposed that consumers who suffer from frequent guilt feelings suffer mainly from regret due to inaction, hedonic consumption and self control failures. The higher guilt score group was found to use more coping responses than the others. Although coping responses significantly explained the future behavior of both groups, the explanatory power of coping responses is stronger for the group with higher guilt scores. An improved comprehension of their guilt-inducing behavior could have encouraged these respondents to engage to a greater extent in reparative actions, psychological repair work and justification as well as affecting their future behavior. Justification was found as the most employed coping response of both groups, whereas the group with lower guilt scores also engaged in reparative action.

The findings may assist marketing practitioners in their attempts to exploit consumer guilt. For instance, marketing messages that rely on regret due to inaction, self-control failures and hedonic consumption may provide powerful results. Marketing practitioners may also address to unfulfilled consumer needs. Relying on regret due to the purchase of utilitarian products associated with a perception of lower consumer value, marketing practitioners may try to provide consumers reasons to justify their guilt due to indulgence, self-control and promotion failures. Marketing practitioners may also try to decrease proceeding guilt, the most frequent experienced guilt feeling by giving justification reasons at the point of purchase. Moreover, practitioners may also develop solutions to help consumers to overcome post-purchase dissonance; for instance, providing clear instructions how to ask for a refund when consumers have made a purchase which they subsequently regret and simplifying the procedure may be a good way for it.

The findings of the present study contribute to the growing literature on consumer guilt by offering a comprehensive structural model of consumer guilt, its antecedents and consequences. However, the findings need to be reviewed critically in the light of its limitations. Due to budgetary limitations, the data were collected only in once city, Izmir, in Turkey, which is a developing, yet still less affluent country. Embracing a diverse population with various ethnic and religious backgrounds of inhabitants, Izmir, Turkey's third most populous city, is well-known for its westernized consumptionscape. Considering economical and social diversities between the western and eastern parts of Turkey, it is unlikely that the sample represents the general Turkish population. Thus, additional work will be needed to validate proposed the structural model via more comprehensive samples. 


\section{REFERENCES}

Bagozzi, R. P., Baumgartner, H., Pieters, R., Zeelenberg, M. (2000) "The Role Of Emotions in Goal-Directed Behavior" S. Ratneshwar, D. G Mick, C. Huffman (eds.) The Why of Consumption: Contemporary Perspectives on Consumers Motives, Goals and Desires, London, Routledge.

Baumeister, R.F. (2002) "Yielding to Temptation: Self-Control Failure, Impulsive Purchasing And Consumer Behavior" Journal of Consumer Research, 28(4):670676.

Baumeister, R.F., Stillwell, A.M., Heatherton, T.F. (1995) "Personal Narratives About Guilt: Role in Action Control And İnterpersonal Relationships" Basic and Applied Social Psychology, 17(1/2): 173-198.

Bei, L. T., Lin, Y. T, Yu, C. M. (2007) "The Relationship Between Consumer Guilt And Shopping Behavior" in G. Fitzsimons, V. Morwitz (eds). Advances in Consumer Research, 34, Duluth, MN : Association for Consumer Research, 405-408.

Belk, R. W., Ger, G., Askegaard, S. (2003) "The Fire of Desire: A Multisided Inquiry into Consumer Passion" Journal of Consumer Research, 30(3):326-351.

Ben-Ze'ev, A. (2000) The Subtlety of Emotions, USA, MIT Press.

Bonsu, S, Main, K. (2006) "Consumer Guilt: Preliminary Construct Assessment And Scale Development" M. C. Lees, T. Davis, G. Gregory (eds.) Asia-Pacific Advances in Consumer Research, Sydney, Australia, Association for Consumer Research.

Boujbel, L. (2008) "Never-Ending Desires: Assessing Consumers' Propensity to Desire Consumption Objects" S. Borghini, M.A. McGrath, C. Otnes (eds.) European Advances in Consumer Research, Duluth, MN, Association for Consumer Research.

Burnett, M. S, Lunsford, D. A. (1994) "Conceptualizing Guilt in The Consumer Decision-Making Process" Journal of Consumer Marketing, 11(3):33-43.

Cervone, D., Shadel, W. G., Smith, R. E, Fiori, M. (2006) "Self-Regulation: Reminders And Suggestions From Personality Science" Applied Psychology: An International Review, 55(3): 333-385.

Chun, H., Patrick, V. M, MacInnis, D. J. (2007) "Making Prudent Vs. Impulsive Choices: The Role of Anticipated Shame And Guilt on Consumer SelfControl" G. Fitzsimons, V. Morwitz (eds.) Advances in Consumer Research, Duluth, MN, Association for Consumer Research.
Connolly, T, Zeelenberg, M. (2002) "Regret in Decision Making" Current Directions in Psychological Science, 11(6):212-216.

Cooke, A. D. J., Meyvis, T., Schwartz, A. (2001) "Avoiding Future Regret in Purchase-Timing Decisions" Journal of Consumer Research, 27(4): 447-459.

Cotte, J, Ritchie, R. (2005) “Advertisers' Theories of Consumers: Why Use Negative Emotions to Sell?" G. Menon, A.R. Rao (eds.) Advances in Consumer Research, Duluth, MN, Association for Consumer Research.

Dahl, D. W., Honea, H, Manchanda, R.V. (2003) "The Nature of Self-Reported Guilt in Consumption Contexts" Marketing Letters, 14(3):159-171.

Dahl, D. W., Honea, H, Manchanda, R.V. (2005) "Three Rs of Interpersonal Consumer Guilt: Relationship, Reciprocity, Reparation” Journal of Consumer Psychology, 15(4):307-315

Dedeoglu, A.O., Kazançoglu I. (2010) "The Feelings of Consumer Guilt: A Phenomenological Exploration” Journal of Business, Economics and Management, 11(3): 462-482.

Duhachek A. (2005) "Coping: A Multidimensional, Hierarchical Framework of Responses to Stressful Consumption Episodes" Journal of Consumer Research, 32 (1):41-53.

Elison, J. (2005) "Shame And Guilt: A Hundred Years of Apples and Oranges" New Ideas in Psychology, 23(1):5-32.

Eppright, D. R., Hunt, J. B., Tanner, J. F., Jr., Franke, G. R. (2002) "Fear, Coping, And Information: A Pilot Study On Motivating A Healthy Response" Health Marketing Quarterly, 20(1):51-73.

Etxebarria, I. (2000) "Guilt: An Emotion Under Suspicion" Psicothema, 12:101-108.

Faber, R. J. (2000) "The Urge to Buy: A Uses and Gratifications Perspective on Compulsive Buying" S. Ratneshwar, D. G Mick, C. Huffman (eds.) The Why of Consumption: Contemporary Perspectives on Consumers Motives, Goals and Desires, London, Routledge.

Godwin, B.F., Patterson, P.G., Johnson L.W. (1999) "Consumer Coping Strategies with Dissatisfactory Service Encounters: A Preliminary Investigation" Journal of Customer Satisfaction, Dissatisfaction and Complaining Behavior, 12:145-154.

Hassay, D. N, Smith, M. C. (1996) "Compulsive Buying: An Examination of the Consumption Motive" Psychology and Marketing, 13(8):741-752. 
Hirschman, E. C, Holbrook, M. B. (1982) "Hedonic Consumption-Emerging Concepts, Methods and Propositions" Journal of Marketing, 46(3):92-101.

Huhmann, B. A, Brotherton, T. P. (1997) "A Content Analysis Of Guilt Appeals in Popular Magazine Advertisements" The Journal of Advertising, 26(2):35-45.

Khan, U., Dhar, R., Fishbach, A. (2009) "Guilt As Motivation: The Role of Guilt in Choice Justification" A.L. McGill, S. Shavitt (eds.) Advances in Consumer Research, Duluth, MN, Association for Consumer Research.

Keinan, A, Kivetz, R. (2008) "Remedying Hyperopia: The Effects of Self-Control Regret on Consumer Behavior" Journal of Marketing Research, 45(6):676-689.

Kivetz, R, Keinan, A. (2006) "Repenting Hyperopia: An Analysis of Self-Control Regrets" Journal of Consumer Research, 33(2):273-282.

Kivetz, R., Simonson, I. (2002) "Self-Control for the Righteous:Toward a Theory of Precommitment to Indulgence" Journal of Consumer Research, 29:199-217.

Lazarus, R.S. (1991) Emotion and Adaptation, New York, Oxford University Press.

Lazarus, R. S., Folkman, S. (1984) Stress Appraisal, and Coping, New York, Springer.

Lascu, D. N. (1991) "Consumer Guilt - Examining The Potential of A New Marketing Construct” R.H. Holman, M.R. Solomon (eds.) Advances in Consumer Research, Provo, UT, Association for Consumer Research.

Lin, Y.T., Xia, K.N. (2009) "The Relationship Between Consumer Guilt and Product Categories" S. Samu, R. Vaidyanathan, D. Chakravarti (eds.) Asia-Pacific Advances in Consumer Research, Duluth, MN, Association for Consumer Research.

Luce M.F. (1998) "Choosing to Avoid: Coping with Negatively Emotion-Laden Consumer Decisions” Journal of Consumer Research, 24(4):409-433

MacInnis, D. J, Patrick, V. M. (2006) "Spotlight on Affect: Affect and Affective Forecasting in Impulse Control" Journal of Consumer Psychology, 16(3):224-231.

Meyvis, T, Cooke, A. D. J. (2007) "Learning From Mixed Feedback: Anticipation of the Future Reduces Appreciation of the Present" Journal of Consumer Research, 34(2):200-211.

Miao, L. (2011) "Guilty Pleasure or Pleasurable Guilt? Affective Experience of Impulse Buying in HedonicDriven Consumption" Journal of Hospitality and Tourism Research, 35 (1):79-101.
Mukhopadhyay A., Johar G.V. (2007) "Tempted or Not? The Effect of Recent Purchase History on Responses to Affective Advertising" Journal of Consumer Research, 33:445-453.

Norum, P. S. (2008) "The Role of Time Preference and Credit Card Usage in Compulsive Buying Behaviour" International Journal of Consumer Studies, 32(3):269275.

O'Guinn, T. C, Faber, R. J. (1989) "Compulsive Buying: A Phenomenological Exploration" Journal of Consumer Research, 16(2):147-157.

Okada, E. M. (2005) "Justification Effects on Consumer Choice of Hedonic and Utilitarian Goods" Journal of Marketing Research, 42(1):43-53.

O’Keefe D.J. (2002) "Guilt as a Mechanism of Persuasion" J.P. Dillard and and M. Pfau (eds.) The Persuasion Handbook: Developments in Theory and Practice, California, USA, Sage Publucations.

O'Shaughnessy, J, O'Shaughnessy, N. J. (2002) "Marketing, The Consumer Society and Hedonism" European Journal of Marketing, 36(5/6):524-547.

Pieters, R., Zeelenberg, M. (2007) "A Theory of Regret Regulation 1.1", Journal of Consumer Psychology, 17(1):29-35.

Puri, R. (1996) "Measuring and Modifying Consumer Impulsiveness: A Cost-Benefit Accessibility Framework" Journal of Consumer Psychology, 5(2):87-113.

Ramanathan, S, Williams, P. (2007) "Immediate and Delayed Emotional Consequences of Indulgence: The Moderating Influence of Personality Type on Mixed Emotions" Journal of Consumer Research, 34(2):212-223.

Rippetoe, P. A., Rogers, R.W. (1987) "Effects of Components of Protection Motivation Theory on Adaptive and Maladaptive Coping with A Health Threat" Journal of Personality and Social Psychology, 52:596-604.

Roese, N. J., Summerville, A., Fessel, F. (2007) Regret and Behavior: Comment on Zeelenberg and Pieters, Journal of Consumer Psychology 17:25-28.

Rook, D. W. (1987) "The Buying Impulse" Journal of Consumer Research, 14(2):189-199.

Rook, D.W, and Fisher, R. (1995) "Normative Influences in Impulsive Buying Behavior" Journal of Consumer Research, 22: 305-313.

Roseman , I. (1984) "Cognitive Determinants of Emotion: A Structural Theory” P. Shaver (eds.) Review of Personality and Social Psychology: Emotions, Relationships and Health, Beverly Hills, CA, Sage Publucations. 
Saffrey, C., Summerville, A, Roese, N. J. (2008) "Praise For Regret: People Value Regret Above Other Negative Emotions" Motivation and Emotion, 32(1):46-54.

Saldanha, N, Williams, P. (2008) "Mixed Indulgences: When Removing Sin May Backfire" A.Y. Lee, D. Soman (eds.) Advances in Consumer Research, Duluth, MN, Association for Consumer Research.

Sela A., Berger J., Liu W. (2009) "Variety, Vice, and Virtue: How Assortment Size Influences Option Choice" Journal of Consumer Research, 35:941-951.

Sengupta, J., Zhou, R. R. (2007) "Understanding Impulsive Eaters' Choice Behaviors: The Motivational Influences of Regulatory Focus" Journal of Marketing Research, 44(2):297-308.

Soscia, I. (2007) "Gratitude, Delight, or Guilt: The Role of Consumers' Emotions in Predicting Postconsumption Behaviors" Psychology and Marketing, 24(10):871-894.

Soscia, I., Busacca, B, Pitrelli, E. (2008) "Guilt Decreasing Marketing Communication: An Unexplored Appeal" S. Borghini, M.A. McGrath, C. Otnes (eds., European Advances in Consumer Research, Duluth, MN, Association for Consumer Research.

Tangney, J. P. (2003) "Self-relevant Emotions" M. L. Leary, J. P. Tangney (eds.). Handbook of Self and Identity, USA, The Guilford Press.

Tangney, J. P. and Dearing, R.L. (2002) Shame and Guilt, New York, Guildford Press.
Tracy, J.L., Robins R.W., Tangney, J.P. (2007) SelfConscious Emotions: Theory and Research, New York, Guildford Press.

Tanner, J. F., Hunt J. B., Eppright D. R. (1991) "The Protection Motivation Model: A Normative Model of Fear Appeals" Journal of Marketing, 55:36-45.

Tsiros, M, Mittal, V. (2000) "Regret: A Model of its Antecedents and Consequences in Consumer Decision Making" Journal of Consumer Research, 26(4):401-417.

Umeh, K. (2004) "Cognitive Appraisals, Maladaptive Coping, and Past Behavior in Protection Motivation" Psychology and Health, 19(6):719-735.

Vincent, A., Dubinsky, A. J. (2005) "Impact of Fear Appeals in A Cross-Cultural Context" Journal of Euromarketing, 14(1):145-167.

Watson, L., Spence, M. T. (2007) "Causes and Consequences of Emotions on Consumer Behaviour: A Review and Integrative Cognitive Appraisal Theory" European Journal of Marketing, 41(5/6): 487-511.

Xu, J, Schwarz, N. (2009) "Do We Really Need A Reason To İndulge?" Journal of Marketing Research, 46(1):25-36.

Yi, S, Baumgartner, H. (2004) "Coping with Negative Emotions in Purchase-Related Situations" Journal of Consumer Psychology, 14(3):303-317.

Zeelenberg, M, Pieters, R. (2007) "A Theory of Regret Regulation 1.0" Journal of Consumer Psychology, 17(1):3-18. 